\title{
RIGHT-OF-WAY RESOURCES OF THE PRAIRIE PROVINCES
}

\section{by Robert B. Oetting, Manitoba Department of Mines, Winnipeg}

\section{Introduction}

One of the greatest dangers threatening North American wildlife is loss of habitat. The wildlife crisis arising because of intensified land use and expanding human populations is already manifest in reduced wildlife populations and endangered species. The rate at which land is consumed by homes, luildings and transportation facilities is a pressing concern. As man continues to alter his environment he must be sure immediate benefits do not result in long-term losses.

Accounts of squandered resources and destroyed natural areas fill our news media. To counter these trends, wildlife agencies, public and private, have developed programs of land preservation. Wildlife habitat is bought, rented, eased, mitigated and begged, but losses still far exceed gains.

Now other lands of promise await development. These are the right-ofway lands, inseparable kin to roads, highways, railroads, pipelines, utility transmission lines and irrigation and flood control projects. Most of these lands are publicly owned and are potential wildlife habitat.

Some data on wildlife use of rightsof-way have been collected and reported in the course of land use projects, but comparative studies are rare. (Table 1). Joselyn, et al (1968) reported higher Ring-necked Pheasant nest densities and success in unmowed rights-of-way on secondary roads in Illinois than in mowed rights-of-way. Page and Cassel (1971) found higher duck nest densities and success along unmowed railroad right-of-way in North Dakota than along mowed parcels.

Our research (Oetting and Cassel, 1971) along Interstate Highway No. 94 in Stutsman County, North Dakota revealed higher duck nest densities and success in unmowed blocks than in mowed blocks. We studied 630 acres of 1-94 roadside along 23 miles in 1968, 1969 and 1970 . We found 422 duck nests which had an overall success of 57 percent. When alternate one-mile

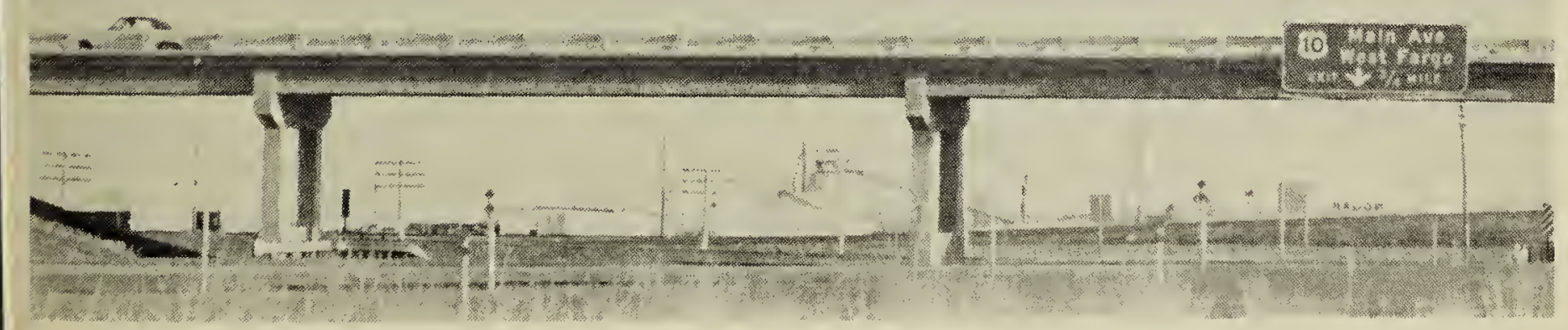

A Ring-necked Pheasant flushes from right-of-way cover along Interstate Highway No. 9 near West Fargo, North Dakota. Game birds in the intensely-farmed Red River Valley rely heavily on rights-of-way for nesting and winter cover. 
blocks of the study area were left unmowed in 1969 and 1970 , significantly more ducks chose unmowed portions for nest sites, and nest success in unmowed blocks rose to 62 percent, while success in mowed blocks was only 51 percent. In addition to ducks, nests of Sharp-tailed Grouse, Gray Partridge, Killdeer, Upland Plover, Mourning Doves and American Bittern were found along the busy Interstate rightof-way.

Our ninal maintenance recommendations to the North Dakota Highway Department included reduced mowing of rights-of-way and later beginning mowing dates, to allow more nests to hatch.

It is gratifying to report that the Department responded to those recommendations and altered maintenance methods on the I-94 right-of-way from Tower City to Tappen, a distance of 78 miles and an area of about 2,000 acres. The Department also delayed the start of mowing on primary and secondary roads from July 5 to July 15 to allow more nests to hatch. In the process the Department has saved nearly $\$ 100,000$ annually in maintenance expenses ( $\mathrm{J}$. Kyser, personal communication) .

\section{Right-of-Way Data}

The Prairie Provinces boast a huge right-of-way resource (Table 2). The highways, roads, railroads, power transmission lines and diversion waterways of Manitoba, Saskatchewan and Alberta cover more than two million acres.

Most of this acreage is located in agricultural areas where its value to wildlife is probably high. In some areas rights-of-way through northern bush country help wildlife by creating edges and openings in solid stands of timber. Many species are found in greatest abundance along such edges or ecotones. In agricultural areas rights-ofway may offer the only cover for game birds and small mammals.

Following are summaries of rightsof-way maintenance information, by province, as reported by various pri-

Table 1. Game bird nests found on rights-of-way compared to other areas searched.

\begin{tabular}{|c|c|c|c|}
\hline State & $\begin{array}{l}\text { Percent of study } \\
\text { area as roadside }\end{array}$ & $\begin{array}{l}\text { Percent of nests } \\
\text { found in roadside }\end{array}$ & Source \\
\hline Nebraska & 1.2 & 28 & $\begin{array}{l}\text { Evans and Wolfe } \\
(1967)\end{array}$ \\
\hline Nebraska & $<1.0$ & 25.1 & $\begin{array}{l}\text { Wolfe and Evans } \\
(1967)\end{array}$ \\
\hline Minnesota & 2.0 & 25 & Chesness (1965) \\
\hline Nebraska & $<2.0$ & 24 & $\begin{array}{l}\text { Linder et al. } \\
(1960)\end{array}$ \\
\hline North Dakota & 1.4 & 57 & Fisher (1955) \\
\hline North Dakota & 2.0 & 43 & Fisher (1954) \\
\hline North Dakota & 2.6 & 27 & $\begin{array}{l}\text { Bach and Stuart } \\
(1942)\end{array}$ \\
\hline North Dakota & \multicolumn{3}{|c|}{$\begin{array}{l}\text { Shorelines and roadside had highest nest densities. } \\
\text { Martz (1967) }\end{array}$} \\
\hline South Dakota & \multicolumn{3}{|c|}{$\begin{array}{r}\text { Pheasant nest densities highest on roadsides and fencerows. } \\
\text { Trautman (1960) }\end{array}$} \\
\hline Manitoba & \multicolumn{3}{|c|}{$\begin{array}{r}\text { Duck nest densities highest on roadsides and hayfields. } \\
\text { Milonski (1958) }\end{array}$} \\
\hline Iowa & \multicolumn{3}{|c|}{$\begin{array}{l}\text { Roadsides best for production of pheasants. } \\
\text { Klonglan (1955) }\end{array}$} \\
\hline Michigan & \multirow{2}{*}{\multicolumn{3}{|c|}{$\begin{array}{l}\text { Majority of pheasants produced in roadsides and ditchbanks. } \\
\text { Schick (1952) } \\
\text { Roadsides preferred by nesting Gray Partridge. }\end{array}$}} \\
\hline$U_{1}$ & & & \\
\hline
\end{tabular}

Hawkins (1937) 
vate and government agencies:

Manitoba: The Department of Public Works and Highways attempts to mow 111,300 right-of-way acres of provincial trunk highways and roads. On main highways one mowing is completed each summer; on other important roads mowing is done only every other year, except for inslopes. In 1970 mowing maintenance cost the Department nearly $\$ 250,000$ and could run as high as $\$ 375,000$ for 1971 . Mowing is usually done in late summer or early fall when most wildlife species have concluded their nesting activities (A. MacLeod, personal communication).

Saskatchewan: The Department of Highways and Transportation mows provincial roads and highways twice per year. A "beautification" mowing is done on 10,000 acres near cities, towns, interchanges, junctions and medians of divided highways. A later mowing is a repeat of the early mowing and a top cut along paved highways. The entire right-of-way (about 30,000 acres) of certain highways is mowed to control noxious weeds and rank growth. A third mowing in fall is performed on inslopes for snow control. Other mowing throughout the summer is designed to retard brush and maintain sight distances. The snow-brush-sight maintenance involves about 50,000 acres. Total right-of-way mowing, litter removal, reseeding and erosion control cosit was $\$ 1,154,220$ in 1970 ( $R$. Scott, personal communication).

The Saskatchewan Power Corporation spends about $\$ 78,000$ annually to sterilize soil around the base of structures in agricultural land and chemically control brush in forested land (M. Offet, personal communication). Pipelines operated by Gulf Oil Canada, Ltd., are buried and require no maintenance (L. Watson, personal communication).

Alberta: The Department of Highways and Transport mows highway inslopes once during the summer and the entire right-of-way once, resulting in a double inslope mowing each year. In some areas adjacent landowners are allowed to take hay or cultivate high-

Table 2. Acreages of various types of right-of-way in the Prairie Provinces.

\begin{tabular}{|c|c|c|c|c|}
\hline \multirow[b]{2}{*}{ Type of right-of-way } & \multicolumn{3}{|c|}{ Approximate acres } & \multirow{2}{*}{$\begin{array}{l}\text { Total by } \\
\text { type }\end{array}$} \\
\hline & Manitoba & Saskatchewan & Alberta & \\
\hline Provincial highways & 72,135 & $140,000^{1}$ & 8,646 & \\
\hline Provincial roads & 84,097 & & 80,436 & \\
\hline Municipal roads & 288,484 & Unknown & 86,400 & \\
\hline Unimproved roads & Unknown & Unknown & 484,848 & \\
\hline TOTAL KNOWN ROADSIDE ${ }^{2}$ & 444,716 & 140,000 & 660,330 & $1,245,046$ \\
\hline $\mathrm{CN}$ railroad & 29,866 & 42,763 & 20,295 & \\
\hline CP railroad & 18,220 & 38,157 & 29,333 & \\
\hline TOTAL KNOWN RAIROAD ${ }^{3}$ & 48,086 & 80,920 & 49,628 & 178,634 \\
\hline Powerlines & 79,260 & 312,410 & 91,857 & 483,527 \\
\hline Water diversions, reservoirs & & & & \\
\hline $\begin{array}{l}\text { drainage ditches, etc } \\
\text { Pipelines }\end{array}$ & 82,803 & $\begin{array}{c}\text { Unknown } \\
27,448\end{array}$ & $\begin{array}{l}\text { Unknown } \\
\text { Unknown }\end{array}$ & $\begin{array}{l}82,803 \\
27,448\end{array}$ \\
\hline TOTAL RIGHT-OF-WAY & & & & \\
\hline ACREAGES & 654,865 & 560,778 & 801,815 & $2,017,458$ \\
\hline
\end{tabular}

Includes both provincial highways and roads.

Does not include driving surfaces, medians, paved shoulders, etc.

Does not include rails or rail ballast. 


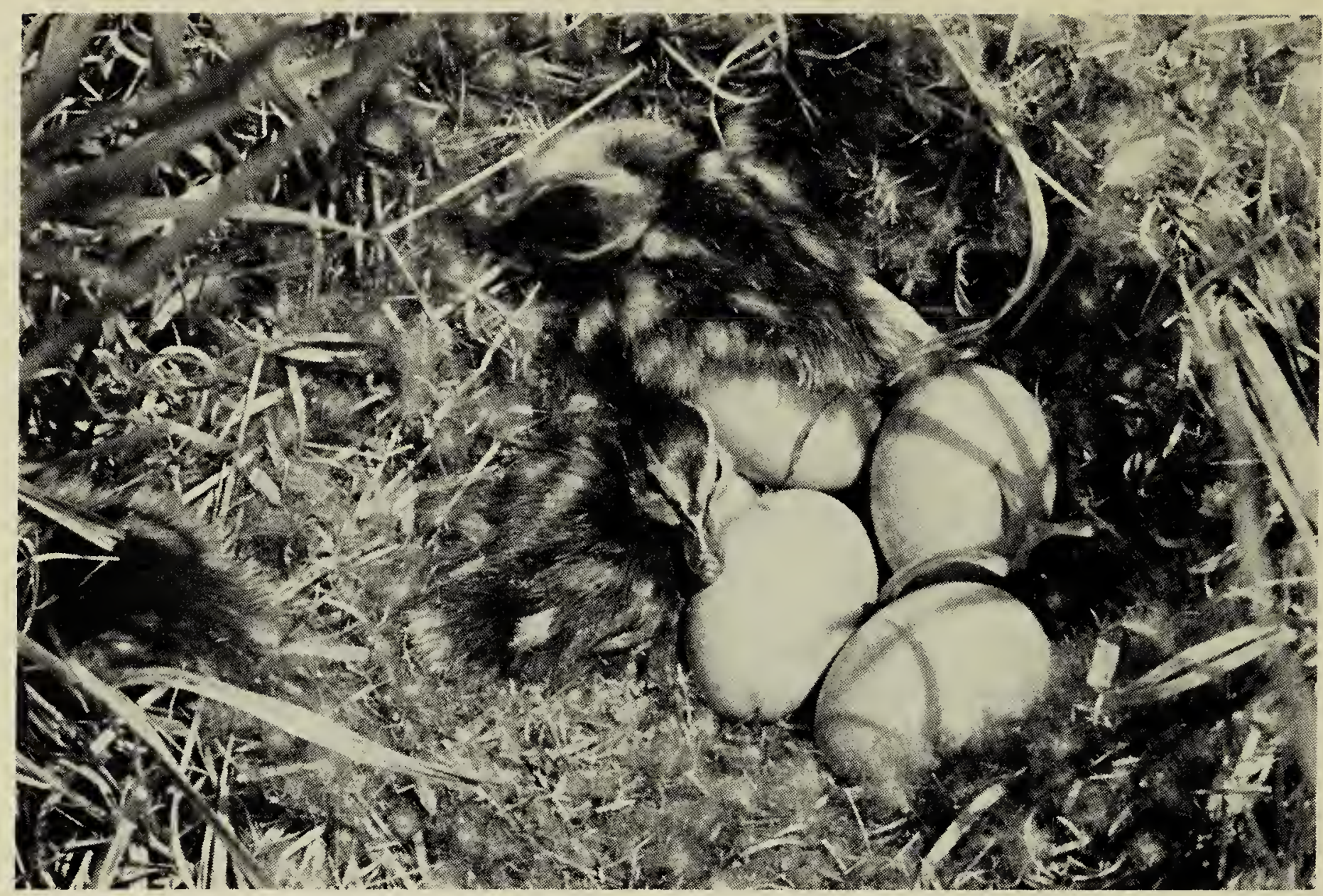

Photo by Ed Bry

Day-old Mallard ducklings explore their environment on the right-of-way of Interstate Highway No. 84 in central North Dakota. These birds hatched three feet from a busy interchange approach ramp.

way rights-of-way. The cost of this mowing maintenance on Alberta highways in 1970 was $\$ 569,000$ (M. Dolin. sky, personal communication). Canadian Utilities Ltd., maintain powerline rigints-of-way chemically or mechanically. The company spent $\$ 121,400$ in 1970 for this maintenance (D. Flory, personal communication).

Discussion

Right-s-of-way of provincial trunk highways, roads and railroads probably cffer the greatest potential for wildlife habitat. Lesser roadsides may be too narrow for game bird production (biologists have found that predators are very efficient at "working" narrow strips).

Railroad right-of-way maintenance is not vigorous. Soil sterilants and herbicides are sprayed on a centre strip about 20 feet wide. The remaining right-of-way receives only local, spot treatment as required.

Where utility transmission lines cross agricultural land their rights-of- way offer little additional wildlife habitat, since they usually are farmed or chemically sterilized. In bush areas, however, utility transmission line rights-of-way may be very important for wildlife.

Drainage and water diversion projects vary in importance to wildlife. Many may be too narrow to support game birds, but could be made more attractive to many other forms of wildlife, including furbearers and song birds. Some larger ones, such as the Red River Floodway near Winnipeg (at least 1,000 acres of habitat) certainly could be easily improved for many kinds of wildlife and recreation facilities.

Pipeline rights-of-way may be negligible in wildlife value since most are buried. Those which are constructed above ground, however, could be improved and may already be benefiting wildlife.

Some income is derived from leasing right-of-way land, but overall main- 
tenance of the Prairie Provinces' rights-of-way remains costly for taxpayers.

How many and what kinds of wildlife could be produced on the rights-ofway of Manitoba, Saskatchewan and Alberta remains to be seen. Some rights-of-way are already contributing; others could be improved. Likewise some are not important for wildlife and may even be detrimental. Intensified land use in southern regions will increase the value of this resource.

Citizens interested in an ecologically sound environment must view Canada's rights-of-way as their own property. Even where right-of-way lands are deeded to a utility or railroad a great deal can be done, for what private business is not interested in an improved environmental image these days?

Conservation groups must lead the way in right-of-way research and stimulate new concepts in right-of-way ecology. No longer can the general public, and especially professional ecologists and wildlife biologists ignore this staggering piece of real estate, which continues to grow at a record pace.

As Canada's environmental awareness sharpens and more potential resources are exploited, it is likely that the taxpayer, who owns most of the right-of-way resource, will demand an accounting.

A unique opportunity is thus at hand for government and railroad officials to "give back" right-of-way lands to the public. This would place native flora and fauna where nearly every citizen could see and enjoy it; it would create living laboratories and preserve strips of natural prairie; it would save many dollars now spent in maintenance. And finally, wild life would increase through proper habitat management.

\section{Acknowledgments}

Gathering right-of-way information from scattered ledgers and field maintenance reports is a difficult and exasperating task. Such figures as total acreage and maintenance costs are usually surprisingly elusive. Those government and private business offi- cials who responded to my research questionnaire did an admirable job in gathering information about their respective right-of-way jurisdictions. Others did not respond and the rightof-way acreages and maintenance costs presented in this paper are therefore considerably underestimated.

I wish to thank A. MacLeod, R. Scott, M. Offet, L. Watson, M. Dolinsky and D. Flory for their efforts in supplying right-of-way information.

\section{LITERATURE CITED}

Bach, R. N. and R. W. Stuart. 1942. North Dakota upland game nesting studies, 1941. North Dakota Game and Fish Dept. P-R Rept. Project 7R. 41pp.

Chesness, R. A. 1965. Ring-neck nesting southern Minnesota style. Cons. Volunteer, $28: 48-51$.

Evans, R. D. and C. W. Wolfe, Jr. 1967. Waterfowl production in the Rainwater Basin area of Nebraska. J. Wildl. Mgmt., 31 :788-794.

Fisher, R. J. 1954. Pheasant nesting, production and movement studies in southwestern North Dakota, 1953. North Dakota Game and Fish Dept. P-R Rept. Project W-35-R-1. $17 \mathrm{pp}$.

Fisher, R. J. 1955. Pheasant nesting studies in southwestern North Dakota, May-October, 1954. North Dakota Game and Fish Dept. P-R Rept. Project W-35-R-2. 27 pp.

Hawkins, A. S. 1937. Roadside nesting of the Hungarian partridge. Trans. N. Am. Wildl. Conf. $2: 481-484$.

Joselyn, G. B., J. E. Warnock, and S. L. Etter. 1968. Manipulation of roadside cover for nesting pheasants-a preliminary report. J. Wildl. Mgmt., 32 :217-233.

Klonglan, E. D. 1955. Pheasant nesting and production in Winnebago County, Iowa, 1954. Proc. Iowa Academy of Sci., 62:626637.

Linder, R. L., D. L. Lyon, and C. P. Agee. 1960. An analysis of pheasant nesting in south central Nebraska. Trans. N. Am. Wildl. and Nat. Resources Conf. 25:214-230.

Martz, G. F. 1967. Effects of nesting cover removal on breeding puddle ducks. J. Wildl. Mgmt., $31: 236-247$.

Milonski, M. 1958. The significance of farmland for waterfowl nesting and techniques for reducing losses due to agricultural practices. Trans. N. Am. Wildl. Conf. 23 :215228.

Oetting, R B., and J. F. Cassel. 1971. Waterfowl nesting on interstate highway rightof-way in North Dakota. In press.

Page, R D., and J. F. Cassel. 1971. Waterfowl nesting on a railroad right-of-way in North Dakota. J. Wildl. Mgmt., 35 :544-549.

Schick, C. 1952. A study of pheasants on the 9,000 -acre prairie farm, Saginaw County, Michigan. Michigan Dept. Cons. $134 \mathrm{pp}$.

Trautman, C. G. 1960. Evaluation of pheasant nesting habitat in eastern South Dakota. Trans. N. Am. and Nat Resources Wildl. Conf. 25 :202-213.

Wolfe, C. W., Jr., and R. D. Evans. 1967. Characteristics of roadside pheasant nests. Nebraska Game and Fish Dept. P-R Rept., Project W-28-R. $14 \mathrm{pp}$. 